\title{
THE EFFECTS OF PARASITES ON HUMAN BEHAVIOUR: AN EVOLUTIONARY PERSPECTIVE
}

\author{
Pavol Prokop \\ Trnava University, Trnava, Slovakia; \\ Institute of Zoology, Slovak Academy of Sciences, Bratislava, Slovakia \\ E-mail: pavol.prokop@savba.sk \\ Peter Fedor \\ Comenius University, Bratislava, Slovakia \\ E-mail: fedor@fns.uniba.sk
}

\begin{abstract}
Parasites and predators possess serious threats to humans throughout our evolutionary history. Although the impact of predators in modern world is lower than previously, parasites still influence morbidity and mortality of contemporary humans. From the evolutionary perspective, selective pressures caused by parasites should favour individuals that successfully avoid objects/subjects which transmit parasitic diseases and/or those who are successful in combats with them. There is growing evidence for the existence of evolved anti-parasite behaviours in animals, beginning with invertebrates and ending with primates. Avoidance of infected individuals, grooming and self-medication are most common behavioural strategies that are believed to reduce the transmission of parasites. Here we review recent evidence suggesting that several behavioural and emotional traits in humans evolved as a response to selective pressure caused by parasites. Disgust sensitivity and pathogen threat may be a mechanism that generates both a cross-cultural variation in preferences for certain facial traits, as well as drivers of religious diversity, political stability of countries, parenting cognitive abilities and prevalence of extraversion and openness to new ideas. Finally, we declare areas for a future research based on questions guided by the evolutionary perspective.
\end{abstract}

Key words: evolution, human, parasites, psychology.

\section{Introduction}

Archaeological evidence had revealed that organisms in the world change over time. Although this was known long ago, the causal mechanism that could explain how and why organisms change was first formulated by Darwin (1859). Darwin's fundamental theory of natural selection proposes that individuals with their phenotypes (including psychological characteristics) better suited for survival in a given environment in a given time over-reproduce individuals with inferior phenotypes. Alleles of more successful individuals are therefore non-randomly distributed in the new generation and, as a result, certain phenotypes are more frequent than others. This leads to a range of morphological and behavioural adaptations designed to enhance the survival of their bearers. The process of natural selection requires three components (Darwin, 1859; Michalski \& Shackelford, 2010): (i) variation of individuals in a population, (ii) heritability of this variation and (iii) differences in reproductive success among individuals that are the subjects of natural selection. Parasites are excellent candidates for studying natural selection, because they are widespread, they have a significant impact on human morbidity and mortality and at least certain psychological mechanisms that enhance 
avoidance of parasites seem to be heritable (Carlson, Katsanis, Iacono, \& McGue, 1997; Peleg et al., 2006; Anokhin, Golosheykin, \& Heath, 2010). The human brain is also a result of evolutionary processes. This paper is predominantly dedicated to psychological mechanisms that are thought to be influenced by natural selection in our evolutionary past to protect humans against the burden of parasites and enhance survival.

\section{Parasites and Human Mortality}

Some of the most striking weapons of natural selection are parasites causing infectious diseases. Their detrimental effect on human morbidity and mortality can be demonstrated by certain well-known examples that have been recently documented. Unfortunately, most of the parasites that form our current disease burden have emerged over the last 11,000 years. This is due to a shift to living in larger groups, which are able to sustain epidemic diseases, and because of close contact with animals via agriculture (Wolfe, Dunavan, \& Diamond, 2007). Thus, our knowledge of parasites that favoured specific psychological adaptations enhancing survival is very limited, and our present ideas are based on reconstructions from relatively recent events. Bacterial diseases wiped out up to $90 \%$ of the native populations in the Americas (Guerra, 1993). In extant hunter-gatherer groups, about $30-50 \%$ of the population dies before reaching reproductive age, most from disease (Hill \& Hurtado, 1996). Plague is caused by the Gram-negative bacterium Yersinia pestis (formerly Pasteurella pestis). Y. pestis was common in rats, but it reproduces in the digestive tract of the oriental rat flea Xenopsylla cheopis, which feeds on the rat's blood (for more details see e.g. Morelli et al. 2010). Infected fleas consequently transmit the disease to humans and/or to domesticated animals if hungry. Plague is usually fatal without antimicrobial treatment. The Bubonic plague, the most dangerous form of plague, has the highest mortality rates - approx. $80 \%$. Infected people most often die within eight days (Totaro, 2005). Looking at historical data, Europe was devastated by Justinian's plague (541-767) and the Black Death (1346-18th century) (Devignant, 1951; Pollitzer, 1951) which also ravaged China (Wu, 1936). Considering that just within the 1300 s the plague killed between $25 \%$ and $50 \%$ of the populations of Europe, Asia and Africa (Gottfried, 1983), this dreaded disease is possibly the most dramatic historically (Morelli et al., 2010). Smallpox, an infectious disease unique to humans, caused by either of two virus variants, Variola major (mortality rate approx. 30 - $35 \%$ ) and Variola minor (mortality rate approx. $1 \%$ ), killed an estimated 400,000 Europeans per year during the closing years of the 18th century (Hays 2005). Before the introduction of rotavirus vaccines, almost all children experienced at least one episode of rotavirus gastroenteritis before the age of 5 (Valencia-Mendoza, Bertozzi, Gutierrez, \& Itzler, 2008). This was estimated to have caused 527,000 deaths and two million hospitalisations per year worldwide (Parashar et al., 2009). The Spanish flu pandemic, caused by the H1N1 influenza virus, which lasted only from 1918 to 1920, killed between 50 and 100 million people (Johnson \& Mueller, 2002) - at least 3\% of the world's population. Tuberculosis is one that has existed for 15,000 - 20,000 years. Tubercle bacillus (Mycobacterium tuberculosis) is spread through the air by the coughing or sneezing of infected people. When left untreated, it kills more than $50 \%$ of those infected. In the mid-nineteenth century, for example, over 300 per 100,000 people died from tuberculosis in England and Wales (Magill, 1955).

\section{The Most Recent Parasite Threats}

Although many diseases have now been eradicated, certain diseases still persist whilst others emerge. For example, current estimates suggest that one to two million people die from malaria annually (Crompton, 1999; Sachs \& Malaney, 2002) and the same number of people died in 2008 due to diseases associated with AIDS (World Health Organization [WHO], 2010). Furthermore, the aforementioned examples are based on lethal diseases, but many non-lethal infectious diseases are harmful to humans and can negatively influence their reproductive success. Consider, for example, lymphatic filariasis, a serious parasitic disease caused by roundworms (mainly Wuchereria bancrofti, which accounts for $90 \%$ of infections, and to a lesser degree Brugia malayi and Brugia timori, which account for the remaining $10 \%$ of infections) spread by mosquitoes - vectors of the disease. Melrose 
(2002) reported that about 120 million people, primarily in Africa, South America and certain other subtropical areas (see Michael, Bundy, \& Grenfell, 1996), are infected are infected. Although not all infected people suffer any obvious effects from these worms (Grove, 1983), if expressed, infected individuals have enormously enlarged limbs, scrotum or other body parts. These people are shunned and avoided by the wider community (Badaki, 2010). Note that filariasis cannot be transmitted from human to human by physical contact like tuberculosis or influenza. Thus, it can be argued that although certain parasites, including those that have a closer relationship with humans (also called "perfect parasites", cf. Kaplan, 2010), are not lethal, they could affect human reproductive success and, as a result, they could also influence the human mind. Two additional pieces of evidence are valid in this argument: firstly, it is suspected that those parasites now considered as "perfect parasites" (e.g., tapeworms Taenia saginata, Taenia solium) are relatively less harmful to humans, because killing their final host is maladaptive due to the restriction of their own fitness (Kaplan, 2010). This, however, suggests that the initial contact of a particular parasite with our ancestors could have serious health consequences that would perhaps account for the negative perception of relatively non-harmful parasites such as tapeworms (Taenia spp.) or roundworms (Ascaris lumbricoides) (Curtis, Aunger, \& Rabie, 2004; Prokop \& Fančovičová, 2010; Prokop, Usak, \& Fančovičová, 2010b). Secondly, "perfect parasites" are considered less harmful to humans, particularly in our current environment, where food availability is high, but the situation in industrialised countries with low resources is different. For example, ascariasis, caused by the roundworm A. lumbricoides, is one of most common parasitic diseases in the world. Overall, about $25 \%$ of the human population is infected (Berger \& Marr, 2006), but the rates of infection in poor areas of Africa are close to 100\% (Berger \& Marr, 2006; Kaplan, 2010). Although infected individuals could remain asymptomatic, heavy worm infestation, associated with nutritional deficiency and obstruction of the bowels, is sometimes fatal (Kaplan, 2010; Baird, Mistrey, Pimsler, \& Connor, 1986). Given our knowledge based on archaeological evidence, this scenario seems to be more realistic for our ancestors, who were obviously more limited in terms of food (Garn \& Leonard, 1989; Ungar \& Teaford, 2002) than for the present Western culture, where food availability and health care is high. Perhaps provocatively, the coiled bodies of parasitic worms could attract our attention and influence our fear when seeing snakes. LoBue and DeLoache (2011) in their current research, found that the speed of detection of coiled wires and coiled snakes in pictures was not different, but coiled objects (either wires or snakes) were more rapidly detected than e.g. flowers. What causes this increased sensitivity to coiled objects? Snakes or parasites?

The examples presented in this sub-chapter suggest that parasites account for a large part of human mortality and morbidity and, from an evolutionary perspective, favoured adaptations that enhance survival. We do not think that estimates of serious diseases fully correspond with those that influenced the evolution of certain behaviours, emotions and cognition in our ancestors; this is especially because certain diseases are relatively "young" and influenced human beings only recently (Wolfe et al., 2007) and the estimation of the prevalence of others is not clear due to a poor knowledge about most diseases. One must consider that sufficient diagnostic techniques have only emerged in the last $100-150$ years. However, these examples illustrate the fact that parasites are ubiquitous and most probably had non-trivial effects on our evolutionary history.

\section{Anti-parasite Behaviour in Animals}

If parasites are selective agents influencing human survival and/or reproduction, natural selection should favour individuals that dispose with certain behavioural strategies that help the individual to avoid infection (Hart, 1990; Loehle, 1995, Parker, Barribeau, Laughton, de Roode, \& Gerardo, 2011). There are several published papers (Curtis, 2007; Parker et al., 2011) and books (Moore, 2002) discussing the anti-parasite behaviour of animals in deeper details. As shown by Moore (2002), anti-parasite behaviours involve a large set of specific behaviours that are believed to reduce the transmission of parasites. Specifically, Moore (2002) proposes that there are the following categories of anti-parasite behaviours: moving away from infection, habitat shifting, adjusting posture, minimising visibility to parasites, grooming/swatting (including the use of tools) and food choice (including self-medication). For a more detailed review of these anti-parasite strategies, I recommend Moore (2002) and Parker et al. (2011). Here, we briefly show certain examples providing evidence for the 
existence of evolved anti-parasite behaviours in animals, beginning with invertebrates and ending with our close relatives - non-human primates.

\section{Avoidance of Infected Individuals or Objects}

Schulenburg and Muller (2004) found that the nematode Caenorhabditis elegans is able to distinguish between innocuous and pathogenic strains of Bacillus thuringiensis and actively keep away from the latter. Interestingly, this avoidance is based on chemical recognition of the bacterium (see Pradel, Zhang, Pujol, Matsuyama, Bargmann, \& Ewbank, 2007), because the bacterium produces a deadly toxin only once it is in the worm's digestive tract. Behringer et al. showed that gregarious Caribbean spiny lobsters (Panulirus argus) avoid conspecifics that are infected with a lethal virus. Interestingly, although lobsters inoculated with a lethal virus developed symptoms of the disease after six weeks and became infectious after eight weeks, most healthy lobsters avoided these inoculated individuals from as early as four weeks. Olfactory cues play a dominant role in the detection of inoculated individuals. This early pathogen detection system confers a selective advantage for (as yet) healthy lobsters in order to reduce their own risk of infection.

Bullfrog tadpoles (Rana catesbeiana) avoid tadpoles with candidiasis Candida humicola, a pathogen that reduces growth rates and can cause the death of tadpoles (Kiesecker, Skelly, Beard, \& Preisser, 1999). Similarly, Bufo americanus tadpoles exhibited avoidance and elevated activity in response to cercariae Echinostoma trivolvis, a trematode that infects and can kill amphibians (Rohr, Swan, Ravel, \& Hudson, 2009). In both cases, parasite avoidance behaviour is stimulated by chemical cues from infected individuals/environments and thus does not require direct contact between individuals. Another experiment performed by Daly and Johnson (2011) where larval Pacific chorus frogs were either anaesthetised or not and exposed to pathogenic trematodes, showed that un-manipulated larvae were significantly less likely to become infected than their anaesthetised counterparts. This evidence collectively suggests that specific behavioural adaptations play an important role in the avoidance of harmful parasites in amphibians.

Rainbow trout (Oncorhynchus mykiss) actively avoid free-swimming larval trematodes that cause cataracts, helping to decrease the rate of infection and severity of pathology (Karvonen, Seppala, \& Valtonen, 2004). Whitefish (Coregonus sp.) respond to the presence of a virulent egg parasite, Pseudomonas fluorescens, by hatching earlier, and this early hatching is induced by water-borne cues emitted from infected eggs (Wedekind, 2002). Certain evidence suggests (albeit not applicable to the example of Coregonus sp.) that anti-parasite responses are not innate but learned. For example, fathead minnows exposed to cercariae of the trematode Ornithodiplostomum sp. showed no evidence of innate recognition or avoidance of cercariae. However, after a single exposure to the cues of the parasite, the fish responded with a reduction in activity, which decreased the encounter rate with the cercariae (James, Noyes, Stumbo, Wisenden, \& Goater, 2008).

Ungulates avoid grazing on forage near their faeces in pastures to reduce infection by faecaloral transmitted parasites (e.g. Dohi, Yamada, \& Entsu, 1991; Ezenwa, 2004). The workers of most social insects exhibit elaborate waste management behaviours and carry their dead out of their nests (Hart \& Ratnieks, 2002; Cremer, Armitage, \& Schmid-Hempel, 2007; Wilson-Rich Spivak, \& Fefferman, 2009).

\section{Grooming}

Both solitary and social organisms can groom themselves (self-grooming), and the rate of selfgrooming significantly increases when individuals are contaminated with pathogens (Reber, Purcell, Buechel, Buri, \& Chapuisat, 2011). Social species are able to groom each other (allo-grooming), which is common in social insects such as ants, wasps, bees and termites (Hölldobler \& Wilson, 1990; Rosengaus, Maxmen, Coates, \& Traniello, 1998; Schmid-Hempel, 1998; Hughes \& Boomsma, 2004; Walker \& Hughes, 2009). In mammals, this is widespread particularly in primates (Goodall, 1986; Dunbar, 1991; Newton-Fisher \& Lee, 2011) and other social mammals such as carnivores (e.g. Stewart, 1997; Kutsukake \& Clutton-Brock, 2006, 2010), rodents (e.g. Stopka \& Macdonald, 1999; Stopka \& Graciasova, 2001) and ungulates (e.g. Hart \& Hart, 1992; Feh \& Demazieres, 1993, 
Mooring \& Hart, 1995). Certain birds use the chemicals in fresh vegetation as fumigants against parasites and pathogens (e.g. Clark \& Mason, 1985, Lafuma, Lambrechts, \& Raymond, 2001) or avoid nests with parasites (Tomas, Merino, Moreno, \& Morales, 2007).

\section{Self-medication}

Great apes are known to use self-medication, i.e. consuming plants with anti-parasite effects, which improve the health of infected individuals (Huffman, 2001). These plants have in particular antiprotozoal or antihelmintical properties (Huffman, 2001; Negre, Tarnaud, Roblot, Gantier, \& Guillot, 2006). Recent research, however, revealed that self-medication is not restricted to mammals (or animals with advanced cognitive abilities in general), but it also works in invertebrates. Woolly bear caterpillars (Grammia incorrupta; Lepidoptera: Arctiidae) ingest plant toxins (pyrrolizidine alkaloids) that improve their survival by conferring resistance against their lethal endoparasites (tachinid flies). Interestingly, excessive ingestion of these toxins reduced the survival rate of caterpillars without parasites, and plant toxins were more likely ingested by caterpillars with parasites than by those without (Singer, Mace, \& Bernays, 2009). Monarch butterflies (Danaus plexippus) infected with the protozoan parasite Ophryocystis elektroscirrha exhibit an oviposition preference for certain species of the milkweed host plant, potentially because of the anti-parasitic effect of secondary plant chemicals (Lefèvre, Oliver, Hunter, \& de Roode, 2010).

\section{Costs of Anti-parasite Behaviour}

One could challenge that if anti-parasite behaviour protects organisms against harmful parasites, then why does this behaviour show inter-individual variability, or why it is not more common? It appears that each strategy has both benefits and costs, although the costs of anti-parasite behaviours are much less known than their benefits (Hughes \& Cremer, 2007). For example, bats spend a considerable amount of time grooming, which is accompanied by a significant increase in oxygen consumption (Giorgi, Arlettaz, Christe, \& Vogel, 2001). Similarly, the fly-swatting behaviour of howler monkeys accounts for $24 \%$ of their metabolic budget (Dudley \& Milton, 1990). Grooming may impose costs on the groomer, including decreased vigilance (Mooring \& Hart, 1995), decreased resting time (Dunbar \& Sharman, 1984; Dunbar, 1992) and exposure to disease (Nunn \& Altizer, 2006). In certain cases, e.g. in the Carpodacus mexicanus house finches, healthy males preferentially forage near same-sex diseased individuals expressing lethargy and lower aggression, which provides feeding benefits on the one hand, but at the cost of transmission of disease on the other (Bouwman \& Hawley, 2010). With respect to self-medication, research showed that excessive ingestion of pyrrolizidine alkaloids in protective plants reduced the survival rate of caterpillars having no parasites (Singer et al., 2009). Consumption of protective plants by monarch butterfly in the absence of a parasite resulted in reduced adult longevity compared with those that fed on a host plant with reduced parasite protection (Lefèvre et al., 2010). In summary, anti-parasite behaviour is both effective in reducing parasites and costly to use.

\section{How Do Parasites Influence Human Behaviour? From Inter-individual to Cross-cultural Differences}

\section{The Persistence of Adaptations}

There are several ways to respond to this question. For example, at least certain parasites directly influence the behaviour of their intermediate hosts to increase the likelihood of being transmitted to their final host (the "manipulation hypothesis", see e.g. Zimmer, 2001; Lefèvre, Adamo, Biron, Misse, Hughes, \& Thomas, 2009). There is plenty of evidence revealing that the parasitic protozoan Toxoplasma gondii, transmitted to its intermediate hosts (rodents), increases activity, preferences for novel areas and overall likelihood of being captured by a cat (for a review see Webster, 2007). Similarly, humans infected by $T$. gondii appeared to lose their concentration more quickly and had a 2.65 times higher risk of traffic accidents than Toxoplasma-free subjects (for a review see Flegr, 2007). A human 
is a dead-end for the parasite, because it is not a suitable final host for parasite reproduction; thus $T$. gondii seem to influence human behaviour in a similar manner as the behaviour of rodents. Finally, Volume 5, 2013 the behavioural and personality differences in infected individuals would account for cross-cultural differences in the prevalence of neuroticism and the avoidance of uncertainty (Lafferty, 2006). This story is a classic example of the „manipulation hypothesis“ applied on humans. However, the aim of this paper is not to show the direct physiological effects of parasites on human hosts, but rather to show how parasites would influence human personality in terms of parasite avoidance.

First of all, we should explain whether or not it is meaningful to think that, in our current, often sterile environment (especially in well-developed countries), any antiparasite behaviour should persist. In fact, the rates of some serious diseases have significantly dropped, which is suggested by recent estimates. Dramatic differences can be observed, especially when including the last 30 years: leprosy dropped from 5.2 million cases in 1985 to 213,036 cases in 2009, and the number of victims of malaria dropped from 2 million annually to 863,000 in 2008 (WHO, 2010). There are no known cases of plague in Europe, and only a few cases were reported in 2009 worldwide (WHO, 2010). One could argue that decreasing the threat of parasites will no longer favour specific behavioural, cognitive and emotional adaptations favouring the survival of our ancestors. Because examples on the persistence of anti-parasite behaviour are relatively scarce, we will start with well-studied examples of anti-predator adaptations. Evidence suggests that anti-predator adaptations shaped by natural selection persisted for many thousands of generations after the sources of selection waned or were no longer present (Schel \& Zuberbuhler, 2009). It is suggested that the cost of maintaining these traits is probably negligible. For example, tammar wallabies (Macropus eugenii) isolated from mammalian predators since the beginning of the Holocene, show evidence of retaining a general ability to recognise the shapes of predators (Blumstein, Daniel, Griffin, \& Evans, 2000). California ground squirrels (Spermophilus beecheyi) retain the ability to recognise their former rattlesnake and gopher snake predators despite living in habitats free or virtually free of these snakes for time frames spanning 70,000 to 300,000 years (Coss, 1991; Coss \& Biardi, 1997). With respect to the persistence of anti-parasite adaptations, research has shown that ungulates, felids and rodents in artificial environments where parasite pressure is low or absent still perform a grooming behaviour (Eckstein \& Hart, 2000a,b; Mooring, Blumstein, \& Stoner, 2004) (there are, however, other explanations for grooming behaviour that is not associated with ectoparasites, see e.g. Newton-Fisher \& Lee, 2011 for discussion). These examples imply that the persistence of anti-parasite behaviour should be expected even in environments almost free of parasites.

Similarly to some animals, detection of perceptual cues of the presence of parasites (appearance, smell, unusual behaviour, etc.) in humans may trigger aversive emotional and cognitive responses that motivate behavioural avoidance.

\section{The Adaptive Significance of Emotions}

The behavioural immune system, which is defined as a set of mechanisms that allows individuals to detect the potential presence of parasites in objects (or individuals) and act to prevent contact with those objects (or individuals), offers a first line of defence against health threatening parasites (Schaller, 2006; Schaller \& Duncan, 2007). The mobilisation of physiological processes - the immunological defence - is costly in terms of energy (Ilmonen, Taarna, \& Hasselquist, 2000) and it is required only after pathogens are in physical contact with the individual's body. Thus, the behavioural immune system is believed to be a cheap but also very effective system that helps to avoid parasite infection.

Pathogen-connoting cues activate centres of disgust in the human brain (Phillips et al., 1997; Phillips, Senior, Fahy, \& David, 1998; Stark et al., 2003) suggesting that the emotional experience of disgust is a key component of the behavioural immune system (Oaten, Stevenson, \& Case, 2009). Disgust is an emotion that can be related to avoidance of certain animals, ill humans, faeces, vomit, sexual substances and other harmful substances or events (Rozin, Haidt, \& McCauley, 2000; Curtis $\&$ Biran, 2001). Disgust may produce specific autonomic responses, such as reduced blood pressure, heart rate deceleration and decreased skin conductance (Stark, Walter, Schienle, \& Vaitl, 2005), as well as the characteristic facial expression. People are obviously disgusted by things that pose a 
real risk of pathogen infection (e.g. faeces, vomit, spoiled food, Curtis \& Biran, 2001), but this is not always true; people are also disgusted by things that do not pose a risk of disease transmission but that simply bear certain superficial resemblance to real risks (e.g. chocolate fudge moulded into the shape of dog faeces; Rozin, Millman, \& Nemeroff, 1986). Social scientists with no evolutionary background would argue that this apparent non-specificity of disgust contradicts its proposed evolutionary origin. The explanation is, however, easy - the behavioural immune system does not react to specific cues triggered by parasites, because these may vary greatly. Instead, it responds in a hypersensitive way to the perceived presence of parasites in the sensory environment (Schaller \& Duncan, 2007). It can be also compared to the 'smoke detector principle' (Nesse, 2005). A smoke detector is usually calibrated to be supersensitive to anything that (albeit superficially) resembles smoke in order to minimise the likelihood of failing to register the presence of real danger - a house fire that would be an extremely costly false-negative error. On the other hand, a false-positive error, e.g. detecting someone smoking in the toilet, is much cheaper that to neglect a dangerous fire.

\section{Individual Differences in Parasite Avoidance}

How does the behavioural immune system work in the real world? First, it can be predicted that the behavioural immune system works superficially, which means that it does not need to always be activated correctly, but particularly if perceptual stimuli resemble disease-connoting stimuli (e.g. avoiding physically impaired people who do not transmit infectious diseases). Second, it can be predicted that people who are more vulnerable to disease transmission (i.e. those who are immunologically compromised) should have a more activated behavioural immune system than others, because they must protect themselves against parasites more often than healthy people with a normal immune system. Current research has shown support for both predictions. Indeed, women in the first trimester of pregnancy, when they are immunologically compromised, are more ethnocentric than during the second and third trimesters (Navarrete, Fessler, \& Eng, 2007). People who think themselves vulnerable to disease transmission show a relatively greater level of aversive response to physically disabled individuals (Park, Faulkner, \& Schaller, 2003), towards older adults (Duncan \& Schaller, 2009), immigrants (Faulkner, Schaller, Park, \& Duncan, 2004), toward obese people (Park, Schaller, \& Crandall, 2007) or toward disease transmitting animals (Prokop, Fančovičová, \& Fedor, 2010a; Prokop, Usak, \& Fančovičová, 2010b; Prokop, Usak, \& Fančovičová, 2010c; Prokop $\&$ Fančovičová, 2013). These people also engage more frequently in various anti-parasite behaviours like avoiding physical contact with pets (Prokop \& Fančovičová, 2010; Prokop et al., 2010a) or disease-transmitting animals (Prokop \& Fančovičová, 2011), and increasing the washing of hands (Porzig-Drummond, Stevenson, Case, \& Oaten, 2009). They also engage more in self-grooming behaviours and less frequently in allo-grooming behaviours, suggesting that the perceived risk of disease stimulates grooming oneself more to maintain health and to reduce ectoparasitic load (Thompson, 2010). One recent, yet unpublished work (Prokop, Ozel, Usak, \& Senay, submitted) showed that the perceived vulnerability to diseases also acts as prevention of consumption of potentially risky foods. Particularly, university students who perceived themselves to be more vulnerable to infection by disease had more negative attitudes toward genetically modified foods, which are perceived to be risky by many people. Stevenson, Case, \& Oaten (2009) showed that participants who had heightened contamination sensitivity and were also more disgust sensitive had significantly fewer recent infections, supporting an idea that the emotion of disgust has a protective effect against infectious diseases. Interestingly, Prokop et al. failed to find any relationships between perceived health and disgust of disease-relevant animals, but perceived danger or fear showed significant negative relationship with perceived health. This suggests that the emotion of fear is additional important component of the behavioural immune system. Furthermore, they found that participants rated disease-relevant animals as more dangerous/disgusting than disease-irrelevant insects, supporting the adaptive significance of our basic emotions (Fig. 1). However, harmless insect larvae or earthworms were rated similarly to disease-relevant insects, supporting the hypersensitiveness of the behavioural immune system. (Prokop \& Fančovičová, 2010). 


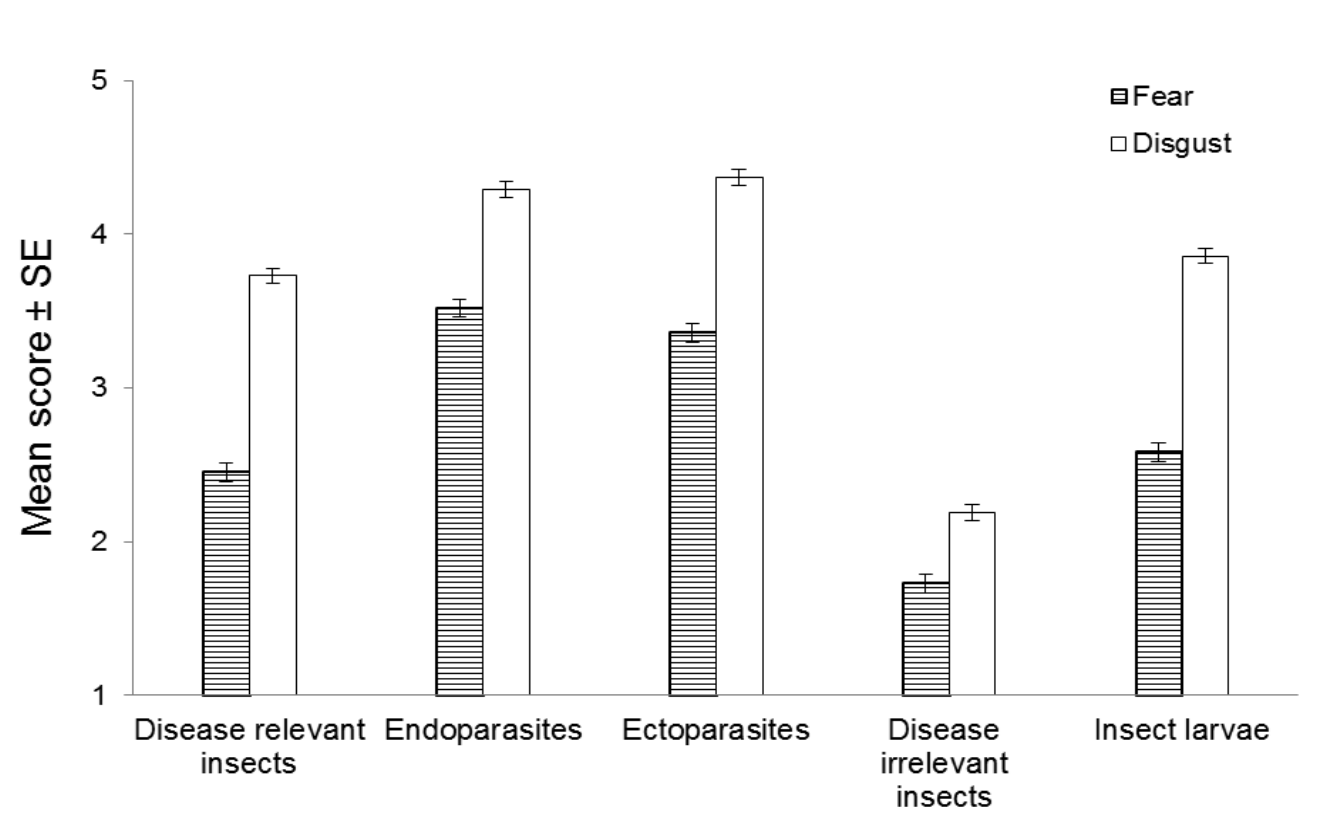

Figure 1: $\quad$ Mean scores of perceived danger and disgust of disease-relevant and disease-irrelevant groups of animals. Details about the sample sizes and statistical differences between groups can be found in the work of Prokop and Fančovičová (2010).

The link between the immune system and the behavioural immune system is still not well understood. Prokop et al. (2010a), for example, found significant and positive associations between perceived health and anti-parasite behaviour (measured by items related to avoidance of pets and personal hygiene), suggesting that healthier people have more anti-parasite behaviours than their less healthy counterparts. The proposed model, based on the results of Prokop et al. (2010a) is presented in Figure 2. People with poor health have a heightened disgust and/or fear of (predominantly) disease-relevant insects, and activation of these emotions produces stronger anti-parasite behaviours. Anti-parasite behaviour is, in turn, associated with better health.

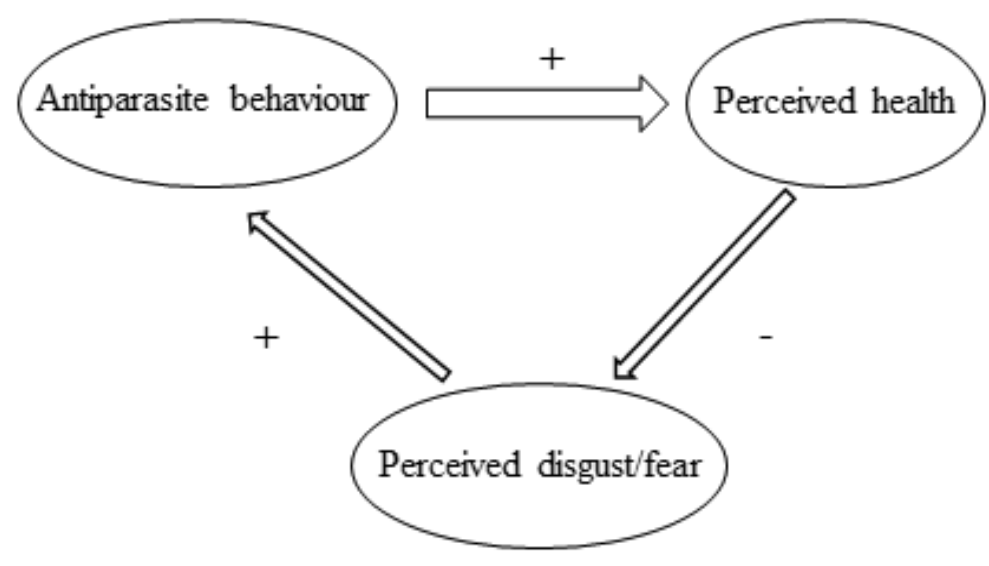

Figure 2: Model of associations between perceived health, anti-parasite behaviour and disgust/fear of disease-relevant invertebrates based on the results of Prokop et al. (2010a). The thickness of arrows reflects the strength of relationships. The signs reflect the direction of relationships.

An alternative to this model is that healthier people can invest to anti-parasite behaviour more, but it seems unlikely that hand washing and/or avoiding physical contact with pets is very costly. Certain personality traits, such as neuroticism, would account for some variance in the obtained cor- 
relation between perceived health and disgust sensitivity (Tybur, Lieberman, \& Griskevicius, 2009).

Note that this study was correlative, so it is not possible to confirm the causation or to exclude the possibility of false results. A more rigorous investigation of the relations between the immune system and anti-parasite strategies is therefore necessary.

\section{Cultural Differences Caused by Parasite Avoidance}

Parasites seem to influence mating preferences (Low, 1990; Gangestad \& Buss, 1993; Gangestad, Haselton, \& Buss, 2006). It has been determined that male masculine traits (large jaws and cheekbones) and facial attractiveness (particularly symmetry) positively correlates with immunocompetence in humans (Thornhill \& Gangestad, 1993, 2006; Rhodes, 2006; Lie, Rhodes, \& Simmons, 2008). In line with this finding, females from areas with high parasite prevalence reveal a preference for more masculine and more facially attractive males than females from parasite free environments (Penton-Voak, Jacobson, \& Trivers, 2004; Little, Jones, \& Burriss, 2007; DeBruine, Jones, Crawford, Welling, \& Little, 2010a). Inter-individual variation in vulnerability to diseases also supports this hypothesis: females who were concerned about pathogens/diseases tend to prefer males with masculine faces more than their less pathogens/disease-vulnerable counterparts (DeBruine, Jones, Tybur, Lieberman, \& Griskevicius, 2010b). This preference is stronger during the ovulation phase of the menstrual cycle, when the likelihood of conception is highest (see Jones, DeBruine, Perrett, Little, Feinberg, \& Law Smith, 2008 for review). Females in environments with a high pathogen prevalence have a more restricted approach to sexual relations (Schaller \& Murray, 2008) which reduces parasite transmission.

Disgust sensitivity and pathogen threat may be a mechanism that generates both a cross-cultural variation in preferences for certain facial traits (i.e. preference for masculine traits in pathogen rich environments, see DeBruine et al., 2010a), as well as drivers of religious diversity (Fincher \& Thornhill, 2008), political stability of countries (Thornhill, Fincher, \& Aran, 2009), parenting (Quinlan, 2007) and cognitive abilities (Eppig, Fincher, \& Thornhill, 2010). In regions characterised by a higher prevalence of parasites, people are less extraverted and less open to new ideas (Schaller \& Murray, 2008) and express greater concern about infection (Prokop et al., 2010c), especially from foreigners (Hamamura \& Park, 2010). Which psychological mechanisms are responsible for these cross-cultural differences ultimately caused by parasites? Fincher, Thornhill, Murray and Schaller (2008), for example, found a positive association between pathogen prevalence and the cultural value of collectivism, arguing that collectivism evolved as effective anti-pathogen psychology. Collectivism is associated with higher ethnocentrism (attraction and support of internal members) and xenophobia (i.e. avoidance of and dislike toward external members) than individualism (Fincher et al., 2008; Thornhill et al., 2009). Collectivism is thought to act as a mechanism for pathogen evasion, whereby individuals avoid strangers who may host potentially infectious diseases to which the individual or community (internal) intruded upon has no immunity. Collectivism and xenophobia are evolutionary mechanisms that cause increased religious diversity in geographic areas with high pathogen stress (Fincher \& Thornhill, 2008). The association between intelligence and parasite threat (Eppig et al., 2010 ) is explained by the high metabolic requirements of the human brain and the trade-off between energy intake and immunological defence against parasites. Longitudinal exposure to energetically costly infectious diseases during the time when the brain is developing negatively influences the quality of the brain, leading to lower intelligence (Eppig et al., 2010). Extraversion and openness to experience may confer specific kinds of benefits (higher number of social contacts, mating opportunities, etc.), but both are associated with specific costs, especially with greater exposure to parasites. This is why areas with high pathogen prevalence are associated with lower extraversion and openness to experience (Schaller \& Murray, 2008). Experimental research by Mortensen, Vaughn Becker, Ackerman Neuberg and Kenrick (2010) supported this idea: exposure to disease primarily led university students to rate themselves as less extraverted.

Evolutionary biologists also found counterstrategies against parasites by comparing birth weight and number of offspring between human populations differing in parasite threat. High parasite prevalence is characterised by the increased weight (Thomas, Teriokhin, Budilova, Brown, Renaud, \& Guégan, 2004) and the number of human offspring (Guégan, Thomas, de Meeüs, Hochberg, \& 
Renaud, 2001). This strategy is considered to be effective, because producing more offspring increases the likelihood of successful survival and reproduction of at least certain children, and a higher birth weight reduces the likelihood of being infected by parasitic diseases. In summary, evolved interindividual differences in parasite avoidance seem to be translated to cross-cultural differences that are ultimately mediated by parasite threat.

A final and very intriguing area of research demonstrating how parasites account for some cross-cultural differences is culinary practises. Certain researchers propose that eating spicy foods might be an effective anti-pathogen strategy (Billing \& Sherman, 1998; Ohtsubo, 2009). Most spices contain secondary compounds that kill bacteria and fungi or inhibit their growth (Billing \& Sherman, 1998), thus, the use of spices, especially in meat-based recipes (Sherman \& Hash, 2001; Ohtsubo, 2009) would be adaptive. Spices could have nutritional and health benefits: e.g. they tend to be antioxidants, which are thought to reduce oxidative damage to cells (Sengul, Ercisli, Yildiz, Gungor, Kavaz, \& Cetin, 2011). It has even been suggested that consumption of turmeric (cucurmin) might contribute to the low prevalence of Alzheimer's disease in India (Gomez Pinilla, 2008). The use of spices might reduce foodborne diseases and food poisoning (Billing \& Sherman, 1998; Yossa, Patel, Miller, \& Lo, 2010). To support this antimicrobial hypothesis, Billing and Sherman (1998) found that recipes from hotter climates, where bacteria and fungi grow more rapidly, called for more spices. Similarly, Ohtsubo (2009) found that unheated Japanese recipes called for more spices and vinegar than heated recipes, which supports the antimicrobial hypothesis. Furthermore, a comparison of traditional recipes from 107 countries showed that spices are used less in preparing vegetables than in preparing meat dishes (Sherman \& Hash, 2001). The authors claim this result is evidence of the antimicrobial hypothesis: cells of dead plants are better protected against bacteria and fungi than the cells of dead animals, so the use of spices makes meat safer for consumption. This research also suggests that if consumption of spices is an adaptive anti-parasite strategy (see also examples for self-medication in animals in this paper), then people more vulnerable to disease should prefer spicy foods more than people less vulnerable to disease. Certain preliminary results support this prediction. Prokop and Fančovičová (2011) found that the reported consumption of spices was positively correlated with the total number of reported illnesses in the last year. This means that immunologically compromised people prefer spices more than their healthier counterparts, supporting the antimicrobial hypothesis (Billing \& Sherman, 1998).

\section{Is Human Nakedness a Result of Parasite Avoidance?}

Although the aim of this paper was to show how parasites influence predominantly human emotion and behaviour, I will briefly review some evidence trying to explain how human nakedness evolved from a view of parasite avoidance. The central idea is purely morphological (lack of body hair), but if parasite avoidance accounts for the evolution of nakedness, then certain psychological mechanisms influencing the preference for naked individuals should evolve, which returns our debate back to anti-parasite behaviour, or, more generally, to the behavioural immune system. Is human nakedness unique? Surely this must be true, because all of our closest relatives (192 species of monkeys and apes) have bodies covered with fur. Recent analyses of DNA suggest that for at least 1.2 million years, humans have been relatively hairless (Rogers, Iltis, \& Wooding, 2004) although the density of their hair follicles is similar to that found in apes of the same body size (Schwartz \& Rosenblum, 1981). Why are we not absolutely naked? This is most probably due to the different functions of head hair and hair in the pubic region. It has been proposed that the former are selected by natural selection, because they protect the head against exposure to the sun, rain and cold, and the latter are thought to be conductive for pheromone signalling between the sexes (Pagel \& Bodmer, 2003). So, how did it appear that humans are almost naked?

Here I will introduce only some hypotheses on human nakedness. I recommend Rantala (2007) for more detailed evaluation of all the existing hypotheses. It has been proposed that the loss of body hair evolved as a response to change in habitat and foraging behaviour. By abandoning the shady forest, our ancestors exposed themselves to higher temperatures, thus hairlessness served as a cooling device (e.g., Morris, 1967). Wheeler (1984) has argued that the reduction of body hair was made possible by the lowered direct solar radiation fluxes which our bipedal ancestors became more and 
more used to. However, the hypothesis does not stand close scrutiny, because although exposure of the naked skin to the air increases the chances of heat loss, it also at the same time increases heat gain and risks damage from the sun's rays. Furthermore, loss of body hair increases perspiration, leading to dehydration; this in turn may be detrimental in a dry savannah environment. A haired hominid in an open hot environment should actually increase its insulation rather than decrease it (Rantala, 2007). Moreover, as males were predominantly hunters and female gatherers (Kaplan, 1996), it would be expected that males in particular should lose body hair if bare skin facilitates hunting prey. However, females were the ones who became the most hairless (Morgan, 1990). Certain authors argue that humans lost body hair as a response to the use of clothes (reviewed by Rantala, 2007). However, why would a hairy animal begin to use clothes in the first place if it already had an insulating coat of body hair?

One of the most prominent explanations of human hairlessness is the "ectoparasite avoidance hypothesis" originally proposed by Belt (1874) and recently rediscovered and elaborated by Rantala $(1999,2007)$ and Pagel and Bodmer (2003). This hypothesis proposes that hairless skin reduces the risk of being infested by ectoparasites, which are vectors of serious diseases some of which have lethal consequences (see Parasites and human mortality subchapter). Females which stays in the vicinity of camps were more vulnerable to parasites than males, because certain parasites (such as fleas) can only complete their life cycle if their host animal lives in a permanently inhabited dwelling (Morris, 1994). Thus natural selection operates in particular against females with dense hair. Hairless females were less vulnerable to parasites and infectious diseases, had higher reproductive success and produced offspring with less hair (Rantala, 1999). They would be consequently preferred more by males and would produce more hairless children and hairless individuals who would tend to prefer hairless mates. Because hairlessness is heritable (Rogers et al., 2004), the result of this "run-away" selection (Fisher 1915), would be the almost completely hairless modern human (Pagel \& Bodmer, 2003; Rantala 1999, 2007). The process is termed "run-away" because over time, it would facilitate the development of a greater preference and more pronounced traits, until the costs of producing the trait balance the reproductive benefit of possessing it (Fisher, 1915).

Do we have any evidence supporting the "ectoparasite avoidance hypothesis"? Unfortunately, palaeontological evidence is very scarce and probably not helpful in testing this hypothesis. However, parasite avoidance in this case is hypothesised to be strongly associated with the choice of mate and sensitivity to pathogens. Thus, the "ectoparasite avoidance hypothesis" can be tested from an evolutionary psychology perspective.

As far as I am aware, there are very few (mostly unpublished) papers on this topic. All these papers are based on force-choice tests, where a female participant was asked to choose what male in a black and white picture is more attractive. Each male was photographed two-times: before and after chest hair removal. The males' legs and faces were not shown in the pictures. Rantala, Polkki and Rantala (2010) found that Finnish females prefer pictures of bare males, and this preference was stronger when the risk of conception (i.e. during the ovulation phase of the menstrual cycle) was higher. Older females, however, preferred males with dense chest hair more than younger females. While the former result can be used as support for the ectoparasite avoidance hypothesis mediated by choice of mate, the latter goes against this hypothesis, because older people that are more vulnerable to diseases are expected to avoid cues associated with ectoparasite presence more than younger ones. Interestingly, older people generally are less disgust sensitive, which does not fit with evolutionary explanations of disgust as a protective mechanism against parasite transmission (Oaten et al., 2009). Perhaps we can use the argument of David Buss (2011) that natural selection operates more strongly within young people (who are at the peak of their reproductive activity), and its effect on older people (whose reproductive potential is close to zero or at least very limited) is weaker.

Another set of evidence comes from two studies of Prokop, Rantala and Fančovičová (2012) and Prokop, Rantala, Usak and Senay (in press). These authors suggested that people living in areas with a high pathogen threat should be more sensitive to parasite connoting cues, and they compared female preference for male chest hair in two countries differing in parasite threat (Prokop et al., in press). They did not find any difference between Slovak (low pathogen) and Turkish females in 
the preference of bare males, although there was a strong preference for bare males versus males with chest hair. They also failed to find any correlations between any of the three components of Volume 5, 2013 disgust (pathogen, sexual, moral) and preferences for bare bodies, providing no support for the tested hypothesis. However, participants that were more vulnerable to disease-connoting cues (Germ Aversion subscale, see Duncan, Schaller, \& Park, 2009) preferred bare males, which supports the ectoparasite avoidance hypothesis more. After excluding females that reported the use of hormonal contraceptives, Slovak females in the high conception risk phase preferred males with chest hair less, which supports the ectoparasite avoidance hypothesis, but no similar patterns were found for the sample of Turkish females.

In a second study, Prokop et al. (2012) examined whether or not exposure to the visual cues of pathogens predicts the preferences for male chest hair in a sample of Slovak females. Again, they found that the preference for male chest hair was low (Fig. 3), but they did not find any changes in female preferences after exposure to visual pathogens. Moreover, they also measured disgust sensitivity to pictures of invertebrates (among them were some ectoparasites), but the correlation between disgust sensitivity and preference for male chest hair was not significant.

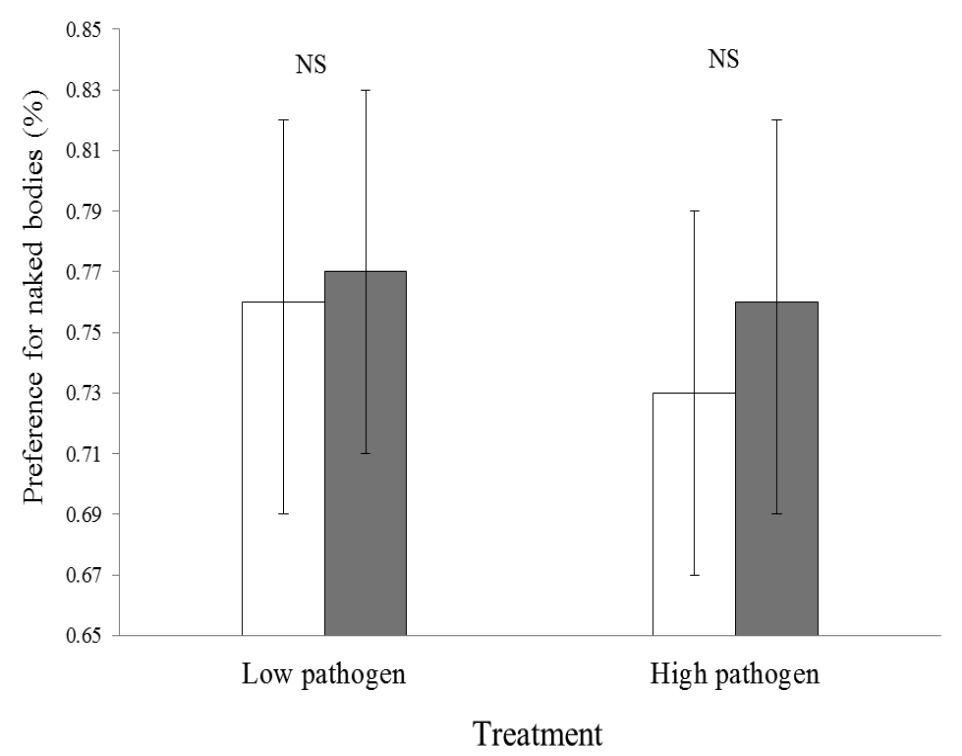

Figure 3: Differences in preference for naked bodies before (open bars) and after exposure (grey bars) to high and low pathogen conditions. Error bars are $\mathbf{9 5} \%$ confidence intervals. NS = not statistically significant.

To summarise, evidence supporting the idea that our ancestors avoided individuals with dense body hair to avoid ectoparasite transmission are very scarce, and, due to mixed results, any conclusion is premature.

\section{Conclusion and Future Directions}

Evidence suggests that parasites play a much more important role in our lives than previously thought, starting from psychological characteristics and inter-individual differences in parasite avoidance at the cognitive, emotional and behavioural level and ending in cross-cultural differences in cognitive abilities, choice of mate, political stability, parenting practises, religious diversity or culinary practises. Some evidence suggests that human nakedness is also a result of ectoparasite avoidance. Most of this evidence is correlative in nature; thus, only future research will show whether alternative explanations are, or are not, more convincing in explanations of cross-cultural differences from the view of parasite avoidance. Evolutionary psychology, however, provides an opportunity to test the questions on human anti-parasite behaviour experimentally. More experimental research integrating biology, ecology, evolutionary psychology and immunology is a promising way of how to uncover the physiological mechanisms responsible for the activation of the behavioural immune system. 


\section{Acknowledgement}

David Livingstone improved the English of this paper. This study was funded by grant VEGA no. $1 / 0137 / 11$.

\section{References}

Anokhin, A. P., Golosheykin, S., \& Heath, A. C. (2010). Heritability of individual differences in cortical processing of facial affect. Behavior Genetics, 40, 178-185.

Badaki, J. A. (2010). Parasitological and social aspects of lymphatic filariasis in Taraba state. Ph.D. Thesis, University of Jos, $150 \mathrm{pp}$.

Baird, J. K., Mistrey, M., Pimsler, M., \& Connor, D. H. (1986). Fatal human ascariasis following secondary massive infection. American Journal of Tropical Medicine and Hygiene, 35, 314-318.

Behringer, D. C., Butler, M. J., \& Shields, J. D. (2006). Avoidance of disease by social lobsters. Nature, 441, 421.

Belt, T. (1874). The naturalist in Nicaragua. $1^{\text {st }}$ edition. London: John Murray, $440 \mathrm{pp}$.

Berger, S. A., \& Marr, J. S. (2006). Human parasitic diseases sourcebook. 1st edition. Sudbury, Massachusetts: Jones and Bartlett Publishers, 300 pp.

Billing, J., \& Sherman, P.W. (1998). Antimicrobial functions of spices: Why some like it hot. Quarterly Review of Biology, 73, 3-49.

Blumstein, D. T., Daniel, J. C., Griffin, A. S., \& Evans, C. S. (2000). Insular tammar wallabies (Macropus eugenii) respond to visual but not acoustic cues from predators. Behavioral Ecology, 11, 528-535.

Bouwman, K. M., \& Hawley, D. M. (2010). Sickness behaviour acting as an evolutionary trap? Male house finches preferentially feed near diseased conspecifics. Biology Letters, 6, 462-465.

Buss, D. (2011). Evolutionary Psychology: The New Science of the Mind. 4th edition. Boston, MA: Prentice Hall, $480 \mathrm{pp}$.

Carlson, R. S., Katsanis, J., Iacono, W. G., \& McGue, M. (1997). Emotional modulation of the startle reflex in twins: preliminary findings Biological Psychology, 10, 235-246.

Clark, L., \& Mason, J. R. (1985). Use of nest material as insecticidal and antipathogenic agents by the European starling. Oecologia, 67, 169-176.

Coss, R. G. (1991). Context and animal behavior: 3. The relationship between early development and evolutionary persistence of ground squirrel antisnake behavior. Ecological Psychology, 3, 277-315.

Coss, R. G., \& Biardi, J. E. (1997). Individual variation in the antisnake behavior of California ground squirrels (Spermophilus beecheyi). Journal of Mammalogy, 78, 294-310.

Cremer, S., Armitage, S. A. O., \& Schmid-Hempel, P. (2007). Social immunity. Current Biology, 17, 693702.

Crompton, D. W. T. (1999). How much human helminthiasis is there in the world? Journal of Parasitology, $85,397-403$.

Curtis, V. (2007). Dirt, disease, and disgust: A natural history of hygiene. Journal of Epidemiology and Community Health, 61, 660-664.

Curtis, V., Aunger, R., \& Rabie, T. (2004). Evidence that disgust evolved to protect from risk of disease. Proceedings of the Royal Society of London, 271, 131-133.

Curtis, V., \& Biran, A. (2001). Dirt, disgust, and disease: Is hygiene in our genes? Perspectives in Biology and Medicine, 44, 17-31.

Daly, E.W., \& Johnson, P. T. J. (2011). Beyond immunity: quantifying the effects of host anti-parasite behavior on parasite transmission. Oecologia, 165, 1043-1050.

Darwin, C. (1859). On the origin of species by means of natural selection, or the preservation of favoured races in the struggle for life. 1st edition. London: John Murray, $502 \mathrm{pp}$.

DeBruine, L. M., Jones, B. C., Crawford, J. R., Welling, L. L. M., \& Little, A. C. (2010a). The health of a nation predicts their mate preferences: Cross-cultural variation in women's preferences for masculinized male faces. Proceedings of the Royal Society of London, 277, 2405-2410. 
DeBruine, L.M., Jones, B.C., Tybur, J. M., Lieberman, D., \& Griskevicius, V. (2010b). Women's preferences for masculinity in male faces are predicted by pathogen disgust, but not moral or sexual disgust. Evolution and Human Behavior, 31, 69-74.

Devignat, R. (1951). Variétés de l'espèce Pasteurella pestis. Nouvelle hypothèse. Bulletin of the World Health Organization, 4, 247-263.

Dohi, H., Yamada, A., \& Entsu, S. (1991). Contaminant losses in overland flow from cattle, deer and sheep dung. Journal of Chemical Ecology, 17, 1197-1203.

Dudley, R., \& Milton, K. (1990). Parasite deterrence and the energetic costs of slapping in Howler monkeys, Alouatta palliata. Journal of Mammalogy, 71, 463-465.

Dunbar, R. I. M. (1991). Functional significance of social grooming in primates. Folia

Primatologica, 57, 121-131.

Dunbar, R. I. M. (1992). Neocortex size as a constraint on group-size in primates. Journal of Human Evolution, 22, 469-493.

Dunbar, R. I. M., \& Sharman, M. (1984). Is social grooming altruistic? Zeitschrift für Tierpsychologie, 64, 163-173.

Duncan, L. A., \& Schaller, M. (2009). Prejudicial attitudes toward older adults may be exaggerated when people feel vulnerable to infectious disease: evidence and implications. Analyses of Social Issues and Public Policy, 9, 97-115.

Duncan, L. A., Schaller, M., \& Park, J. H. (2009). Perceived vulnerability to disease: Development and validation of a 15-item self-report instrument. Personality and Individual Differences, 47, 541-546.

Eckstein, R. A., \& Hart, B. L. (2000a). Grooming and control of fleas in cats. Applied Animal Behaviour Science, 68, 141-150.

Eckstein, R. A., \& Hart, B. L. (2000b). The organization and control of grooming in cats. Applied Animal Behaviour Science, 68, 131-140.

Eppig, C., Fincher C. L., \& Thornhill, R. (2010). Parasite prevalence and the worldwide distribution of cognitive ability. Proceedings of the Royal Society, 277, 3801-3808.

Ezenwa, V. O. (2004). Selective defecation and selective foraging: Antiparasite behavior in wild ungulates? Ethology, 110, 851-862.

Faulkner, J., Schaller, M., Park, J. H., \& Duncan, L. A. (2004). Evolved disease-avoidance processes and contemporary xenophobic attitudes. Group Processes and Intergroup Behavior, 7, 333-353.

Feh, C., \& Demazieres, J. (1993). Grooming at a preferred site reduces heart-rate in horses. Animal Behaviour, 46, 1191-1194.

Fincher, C. L. \& Thornhill, R. (2008). Assortative sociality, limited dispersal, infectious disease and the genesis of the global pattern of religion diversity. Proceedings of the Royal Society of London, 275, 2587-2594.

Fincher, C. L., Thornhill, R., Murray, D. R., \& Schaller, M. (2008). Pathogen prevalence predicts human cross-cultural variability in individualism/collectivism. Proceedings of the Royal Society of London, 275, 1279-1285.

Fisher, R. A. (1915). The evolution of sexual preference. Eugenics Review, 7, 184-192.

Flegr, J. (2007). Effects of Toxoplasma on human behavior. Schizophrenia Bulletin, 33, 757-760.

Gangestad, S. W., \& Buss, D. M. (1993). Pathogen prevalence and human mate preferences. Ethology and Sociobiology, 14, 89-96.

Gangestad, S. W., Haselton, M. G., \& Buss, D. M. (2006). Evolutionary foundations of cultural variation: evoked culture and mate preferences. Psychological Inqury, 17, 75-95.

Garn, S. M., \& Leonard, W. R. (1989). What did our ancestors eat? Nutrition Reviews, 47, 337-345.

Giorgi, M. S., Arlettaz, R., Christe, P., \& Vogel, P. (2001). The energetic grooming costs imposed by a parasitic mite (Spinturnix myoti) upon its bat host (Myotis myotis). Proceedings of the Royal Society of London, 268, 2071-2075.

Gomez Pinilla, F. (2008). Brain foods: the effects of nutrients on brain function. Nature Reviews Neuroscience, 9, 568-78. 
OF PSYCHOLOGY

IN THE $21^{\text {st }}$ CENTURY Volume 5, 2013

60

Goodall, J. (1986). Social rejection, exclusion, and shunning among the Gombe chimpanzees. Ethology and Sociobiology, 7, 227-236.

Gottfried, R. S. (1983). The Black Death: Natural and Human Disaster in Medieval Europe. New York: The Free Press, 203 pp.

Grove, D. I. (1983). Selective primary health care: Strategies for the control of disease in the developing world. VII. Filariasis. Clinical Infectious Diseases, 5, 933-944.

Guégan, J. F., Thomas, F., de Meeüs, T., Hochberg, M. E., \& Renaud, F. (2001). Disease diversity and human fertility. Evolution, 55, 1308-1314.

Guerra, F. (1993). The European-American exchange. History and Philosophy of the Life Sciences, 15, 313327.

Hamamura, T., \& Park, J. H. (2010). Regional differences in pathogen prevalence and defensive reactions to the "swine flu" outbreak among East Asians and Westerners. Evolutionary Psychology, 8, 506-515.

Hart, B. L. (1990). Behavioral adaptations to pathogens and parasites: Five strategies. Neuroscience and Biobehavioral Reviews, 14, 273-294.

Hart, B., \& Hart, L. (1992). Reciprocal allogrooming in impala, Aepyceros melampus. Animal Behaviour, 44, 1073-1083.

Hart, A. G., \& Ratnieks, F. L. W. (2001). Task partitioning, division of labour and nest compartmentalisation collectively isolate hazardous waste in the leafcutting ant Atta cephalotes. Behavioral Ecology and Sociobiology, 49, 387-392.

Hays, J. N. (2005). Epidemics and pandemics: their impacts on human history. California: ABC-CLIO, 513 pp.

Hill, K., \& Hurtado, A. M. (1996). Ache life history: the ecology and demography of a foraging people. Aldine de Gruyter, New York, 561 pp.

Hölldobler, B., \& Wilson, E. O. (1990). The ants. 1st edition. Cambridge, Mass, USA: Belknap Press of Harvard University Press, $732 \mathrm{pp}$.

Huffman, H. A. (2001). Self-medicative behavior in the African great apes: An evolutionary perspective into the origins of human traditional medicine. BioScience, 51, 651-661.

Hughes, W. O. H., \& Boomsma, J. J. (2004). Genetic diversity and disease resistance in leaf-cutting ant societies. Evolution, 58, 1251-1260.

Hughes, D. P., \& Cremer S. (2007). Plasticity in antiparasite behaviours and its suggested role in invasion biology. Animal Behaviour, 74, 1593-1599.

Ilmonen, P., Taarna, T., \& Hasselquist, D. (2000). Experimentally activated immune defence in female pied flycatchers results in reduced breeding success. Proceedings of the Royal Society of London, 267, 665670.

James, C. T., Noyes, K. J., Stumbo, A. D., Wisenden, B. D., \& Goater, C. P. (2008). Cost of exposure to trematode cercariae and learned recognition and avoidance of parasitism risk by fathead minnows Pimephales promelas. Journal of Fish Biology, 73, 2238-2248.

Johnson, N. P., \& Mueller, J. (2002). Updating the accounts: global mortality of the 1918-1920 „Spanish“ influenza pandemic. Bulletin of the History of Medicine, 76, 105-115.

Jones, B. C., DeBruine, L. M., Perrett, D. I., Little, A. C., Feinberg, D. R., \& Law Smith, M. J. (2008). Effects of menstrual cycle on face preferences. Archives of Sexual Behavior, 37, 78-84.

Kaplan, E. H. (2010). What's eating you?: People and parasites. 1st edition. Princeton, New Yersey: Princeton University Press, $320 \mathrm{pp}$.

Kaplan, H. (1996). A theory of fertility and parental investment in traditional and modern human societies. Yearbook of Physical Anthropology, 39, 91-135.

Karvonen, A., Seppala, O., \& Valtonen, E. T. (2004). Parasite resistance and avoidance behaviour in preventing eye fuke infections in fish. Parasitology, 129, 159-164.

Kiesecker, J. M, Skelly, D. K., Beard, K. H., \& Preisser, E. (1999). Behavioral reduction of infection risk. Proceedings of the National Academy of Sciences of the USA, 96, 9165-9168.

Melrose, W. D. (2002). Lymphatic filariasis: New insights into an old disease. International Journal of Parasitology, 32, 947-960. 
Kutsukake, N., \& Clutton-Brock, T. H. (2006). Social functions of allogrooming in cooperatively breeding meerkats. Animal Behaviour, 72, 1059-1068.

Kutsukake, N. \& Clutton-Brock, T. H. (2010). Grooming and the value of social relationships in cooperatively breeding meerkats. Animal Behaviour, 79, 271-279.

Lafferty, K. D. (2006). Can the common brain parasite, Toxoplasma gondii, influence human culture? Proceedings of the Royal Society of London, 273, 2749-2755.

Lafuma, L., Lambrechts, M. M., \& Raymond, M. (2001).Aromatic plants in bird nests as a protection against blood-sucking flying insects? Behavioural Processes, 56,113-120.

Lefèvre, T., Adamo, S. A., Biron, D. G., Misse, D., Hughes, D., \& Thomas, F. (2009). Invasion of the body snatchers: the diversity and evolution of manipulative strategies in host-parasite interactions. Advances in Parasitology, 68, 45-83.

Lefèvre, T., Oliver, L., Hunter, M. D., \& de Roode, J. C. (2010). Evidence for trans-generational medication in nature. Ecology Letters, 13, 1485-1493.

Lie, H. C., Rhodes, G. \& Simmons, L. (2008). Genetic diversity revealed in human faces. Evolution, 62, 24732486.

Little, A. C., Jones, B. C., \& Burriss, R. P. (2007). Preferences for masculinity in male bodies change across the menstrual cycle. Hormones and Behavior, 31, 633-639.

LoBue V., \& DeLoache J. S. (2011). What's so special about slithering serpents? Children and adults rapidly detect snakes based on their simple features. Visual Cognition, 19, 129-143.

Loehle, C. (1995). Social barriers to pathogen transmission in wild animal populations. Ecology, 76, 326-335.

Low, B. (1990). Marriage systems and pathogen stress in human societies. American Zoologist, 30, 325-339.

Magill, T. P. (1955). The immunologist and the evil spirits. Journal of Immunology, 74, 1-8.

Michalski, R. L., \& Shackelford, T. K. (2010). Evolutionary personality psychology: Reconciling human nature and individual differences. Personality and Individual Differences, 48, 509-516.

Michael, E., Bundy, D. A. P., \& Grenfell, B.T. (1996). Reassessing the global prevalence and distribution of lymphatic filariasis. Parasitology Today, 112, 409-428.

Moore, J. (2002). Parasites and the behavior of animals. 1st edition. New York, NY: Oxford University Press, $338 \mathrm{pp}$.

Mooring, M. S., Blumstein, D. T., \& Stoner, C. J. (2004). The evolution of parasite-defence grooming in ungulates. Biological Journal of the Linnean Society, 81, 17-37.

Mooring, M. S., \& Hart, B. L. (1995). Costs of allogrooming in impala: distraction from vigilance. Animal Behaviour, 49, 1414-1416.

Morelli, G., Song, Y., Mazzoni C. J., Eppinger, M., Roumagnac, P., Wagner, D.M., Feldkamp, M., Kusecek, B., Vogler, A.J., Li, Y., Cui, Y. J., Thomson, N. R., Jombart, T., Leblois, R., Lichtner, P., Rahalison, L., Petersen, J. M., Balloux, F., Keim, P., Wirth, T., Ravel, J., Yang, R. F., Carniel, E., \& Achtman, M. (2010). Yersinia pestis genome sequencing identifies patterns of global phylogenetic diversity. Nature Genetics, 42, 1140-1143.

Morgan, E. (1990). The scars of evolution. London: Souvenir Press, 212 pp.

Morris, D. (1967). The naked ape. London: Jonathan Cape, 252 pp.

Morris, D. (1994). The human animal. London: BBC Books, 224 pp.

Mortensen, C. R., Vaughn Becker, D., Ackerman J. M., Neuberg, S. L., \& Kenrick, D. T. (2010). Infection breeds reticence: The effects of disease salience on self-perceptions of personality and behavioral avoidance tendencies. Psychological Science, 21, 440-447.

Navarrete, C. D., Fessler, D. M. T., \& Eng, S. J. (2007). Elevated ethnocentrism in the first trimester of pregnancy. Evolution and Human Behavior, 28, 60-65.

Negre, A., Tarnaud, L., Roblot, J. F., Gantier, J. C., \& Guillot, J. (2006). Plants consumed by Eulemur fulvus in Comoros Islands (Mayotte) and potential effects on intestinal parasites. International Journal of Primatology, 27, 1495-1517.

Nesse, R. M. (2005). Natural selection and the regulation of defenses: A signal detection analysis of the smoke detector principle. Evolution and Human Behavior, 26, 88-105. 
62 Newton-Fisher, N. E., \& Lee, P. C. (2011). Grooming reciprocity in wild male chimpanzees. Animal Behaviour, $81,439-446$.

Nunn, C. L., \& Altizer, S. M. (2006). Infectious diseases in primates: Behavior, ecology and evolution. Oxford: Oxford University Press, $400 \mathrm{pp}$.

Oaten, M., Stevenson, R. J., \& Case, T. I. (2009). Disgust as a disease-avoidance mechanism. Psychological Bulletin, 135, 303-321.

Ohtsubo, Y. (2009). Adaptive ingredients against food spoilage in Japanese cuisine. International Journal of Food Sciences and Nutrition, 60, 677-687.

Pagel, M., \& Bodmer, W. (2003). A naked ape would have fewer parasites. Biology Letters, 270, 117-S119.

Parashar, U. D., Burton, A., Lanata, C., Boschi-Pinto, C., Shibuya, K., Steele, D., Birmingham, M., \& Glass, R. I. (2009). Global mortality associated with rotavirus disease among children in 2004. Journal of Infectious Diseases, 200, 9-15.

Park, J. H., Faulkner, J., \& Schaller, M. (2003). Evolved disease-avoidance processes and contemporary anti-social behavior: prejudicial attitudes and avoidance of people with physical disabilities. Journal of Nonverbal Behavior, 27, 65-87.

Park, J. H., Schaller, M., \& Crandall, C. S. (2007). Pathogen-avoidance mechanisms and the stigmatization of obese people. Evolution and Human Behavior, 28, 410-414.

Parker, B. J., Barribeau, S. M., Laughton, A. M., de Roode J. C., \& Gerardo, N. M. (2011). Non-immunological defense in an evolutionary framework. Trends in Ecology and Evolution, 26, 242-248.

Peleg, G., Katzir, G., Peleg, O., Kamara, M., Brodsky, L., Hel-Or, H., Keren, D., \& Nevo, E. (2006). Hereditary family signature of facial expression. Proceedings of the National Academy of Sciences of the USA, 103,15921-15926.

Penton-Voak, I. S., Jacobson, A., \& Trivers, R. (2004). Populational differences in attractiveness judgements of male and female faces: comparing British and Jamaican samples. Evolution and Human Behavior, $25,355-370$.

Phillips, M. L., Senior, C., Fahy, T., \& David, A. S. (1998). Disgust: the forgotten emotion of psychiatry. British Journal of Psychiatry, 172, 373-375.

Phillips, M. L., Young, A. W., Senior, C., Brammer, M., Andrew, C., Calder, A.J., Bullmore, E. T., Perrett, D. I., Rowland, D., Williams, S. C. R., Gray, J. A. \& David, A. S. (1997). A specific neural substrate for perceiving facial expressions of disgust. Nature, 389, 495-498.

Pollitzer, R. (1951). Plague studies. 1. A summary of the history and survey of the present distribution of the disease. Bulletin of the World Health Organization, 4, 475-533.

Pradel, E., Zhang Y., Pujol, N., Matsuyama T., Bargmann, C. I., \& Ewbank J. J. (2007). Detection and avoidance of a natural product from the pathogenic bacterium Serratia marcescens by Caenorhabditis elegans. Proceedings of the National Academy of Sciences of the USA, 104, 2295-2300.

Porzig-Drummond, R., Stevenson, R., Case, T. \& Oaten, M. (2009). Can the emotion of disgust be harnessed to promote hand hygiene? Experimental and field-based tests. Social Sciences and Medicine, 68, 10061012.

Prokop, P., \& Fančovičová, J. (2010). The association between disgust, danger and fear of macroparasites and human behaviour. Acta Ethologica, 13, 57-62.

Prokop, P., \& Fančovičová, J. (2011). The effect of owning animals on perceived vulnerability to, and avoidance of, parasitic diseases in humans. Journal of Individual Differences, 32, 129-136.

Prokop, P., \& Fančovičová, J. (2011). Preferences for spicy foods and disgust of ectoparasites are associated with reported health in humans. Psihologija, 44,281-293.

Prokop, P., \& Fančovičová, J. (2013). Self-protection versus disease avoidance: The perceived physical condition is associated with fear of predators in humans. Journal of Individual Differences, 34, 15-23.

Prokop, P., Fančovičová, J., \& Fedor, P. (2010a). Health is associated with anti-parasite behavior and fear of disease-relevant animals in humans. Ecological Psychology, 22, 222-237.

Prokop, P., Ozel, M. \& Usak, M., Senay, I. Perceived vulnerability to diseases predicts conservative attitudes toward genetically modified products. Psihologija, submitted 
Prokop, P., Rantala, M. J., \& Fančovičová, J. (2012). Is plasticity in mating preferences adapted to perceived exposure to pathogens? Acta Ethologica, 15, 135-140.

Prokop, P., Rantala, M. J., Usak, M., \& Senay, I. Is a woman's preference for chest hair in men influenced by parasite threat? Archives of Sexual Behavior, in press

Prokop, P., Usak, M., \& Fančovičová, J. (2010b). Health and the avoidance of macroparasites: A preliminary cross-cultural study. Journal of Ethology, 28, 345-351.

Prokop, P., Usak, M., \& Fančovičová, J. (2010c). Risk of parasite transmission influences perceived vulnerability to disease and perceived danger of disease-relevant animals. Behavioural Processes, 85, 52-57.

Quinlan, R. J. (2007). Human parental effort and environmental risk. Proceedings of the Royal Society of London, 274, 121-125.

Rantala, M. J. (1999). Human nakedness: adaptation against ectoparasites? International Journal for Parasitology, 29, 1987-1989.

Rantala, M. J. (2007). The evolution of nakedness in Homo sapiens. Journal of Zoology, 273, 1-7.

Rantala, M. J., Polkki, M., \& Rantala, L. M. (2010). Preference for human male body hair changes across the menstrual cycle and menopause. Behavioral Ecology, 21, 419-423.

Reber, A., Purcell, J., Buechel, S. D., Buri, P., \& Chapuisat, M. (2011). The expression and impact of antifungal grooming in ants. Journal of Evolutionary Biology, 24, 954-964.

Rhodes, G. (2006). The evolutionary psychology of facial beauty. Annual Review of Psychology, 57, 199226.

Rogers, A. R., Iltis, D., \& Wooding, S. (2004). Genetic variation at the MC1R locus and the time since loss of human body hair. Current Anthropology, 45, 105-108.

Rohr, J. R., Swan, A., Ravel, T. R., \& Hudson, P. J. (2009). Parasites, info-disruption, and the ecology of fear. Oecologia, 159, 447-454.

Rosengaus, R. B., Maxmen, A. B., Coates, L. E., \& Traniello, J. F. A. (1998). Disease resistance: a benefit of sociality in the dampwood termite Zootermopsis angusticollis (Isoptera: Termopsidae). Behavioral Ecology and Sociobiology, 44, 125-134.

Rozin, P., Haidt, J., \& McCauley, C. R. (2000). Disgust. In: M. Lewis \& J. M. Haviland-Jones, Eds., Handbook of emotions (2nd edition). New York: Guilford Press, 2000; pp. 637-653.

Rozin, P., Millman, L., \& Nemeroff, C. (1986). Operation of the laws of sympathetic magic in disgust and other domains. Journal of Personality and Social Psychology, 50, 703-712.

Sachs, J., \& Malaney, P. (2002). The economic and social burden of malaria. Nature, 415, 680-685.

Schaller, M. (2006). Parasites, behavioral defenses, and the social psychological mechanisms through which cultures are evoked. Psychological Inquiry, 17, 96-101.

Schaller, M., \& Duncan, L. A. (2007). The behavioral immune system: Its evolution and social psychological implications. In: Forgas, J. P., Haselton, M. G. \& von Hippel, W. Eds. Evolution and the social mind. New York: Psychology Press; pp. 293-307.

Schaller, M., Miller, G. E., Gervais, W. M., Yager, S., \& Chen, E. (2010). Mere visual perception of other people ${ }^{\text {' }}$ disease symptoms facilitates a more aggressive immune response. Psychological Science, $21,649-652$.

Schaller, M., \& Murray, D. R. (2008). Pathogens, personality and culture: Disease prevalence predicts worldwide variability in sociosexuality, extraversion, and openness to experience. Journal of Personality and Social Psychology, 95, 212-221.

Schel, A. M., \& Zuberbuhler, K. (2009). Responses to leopards are independent of experience in Guereza colobus monkeys. Behaviour, 146, 1709-1737.

Schmid-Hempel, P. (1998). Parasites in social insects. 1st edition. Princeton, USA: Princeton University Press, 392 pp.

Schulenburg, H., \& Muller, S. (2004). Natural variation in the response of Caenorhabditis elegans towards Bacillus thuringiensis. Parasitology, 128, 433-443.

Schwartz, G. G., \& Rosenblum, L. A. (1981). Allometry of primate hair density and the evolution of human hairlessness. American Journal of Physical Anthropology, 55, 9-12. 
OF PSYCHOLOGY

IN THE $21^{\text {st }}$ CENTURY Volume 5, 2013

64

Stewart, P. D. (1997). The social behaviour of the European badger, Meles meles. Ph.D. Thesis, University of Oxford.

Sengul, M., Ercisli, S., Yildiz, H., Gungor, N., Kavaz, A., \& Cetin, B. (2011). Antioxidant, antimicrobial activity and total phenolic content within the aerial parts of Artemisia absinthum, Artemisia santonicum and Saponaria officinalis. Iranian Journal of Pharmaceutical Research, 10, 49-55.

Sherman, P. W., \& Hash, G. A. (2001). Why vegetable recipes are not very spicy. Evolution and Human Behavior, 22, 147-163.

Singer, M. S., Mace, K. C., \& Bernays, E. A. (2009). Self-medication as adaptive plasticity: Increased ingestion of plant toxins by parasitized caterpillars. PLoS One, 4, e4796

Stark, R., Schienle, A., Walter, B., Kirsch, P., Sammer, G., Ott, U., Blecker, C., \& Vaitl, D. (2003). Hemodynamic responses to fear- and disgust-inducing pictures. International Journal of Psychophysiology, 50, $225-234$.

Stark, R., Walter, B., Schienle, A., \& Vaitl, D. (2005). Psychophysiological correlates of disgust and disgust sensitivity. Journal of Psychophysiology, 19, 50-60.

Stevenson, R. J., Case, T. I., \& Oaten, M. J. (2009). Frequency and recency of infection and their relationship with disgust and contamination sensitivity. Evolution \& Human Behavior, 30, 363-368.

Stopka, P., \& Graciasova, R. (2001). Conditional allogrooming in the herb-field mouse. Behavioral Ecology, $12,584-589$.

Stopka, P., \& Macdonald, D. W. (1999). The market effect in the wood mouse, Apodemus sylvaticus: selling information on reproductive status. Ethology, 105, 969-982.

Thomas, F., Teriokhin, A. T., Budilova, E. V., Brown, S. P., Renaud, F., \& Guégan, J. F. (2004). Human birthweight evolution across contrasting environments. Journal of Evolutionary Biology, 17, 542-553.

Thompson, K. J. P. (2010). Grooming the naked ape: do Perceptions of disease and aggression vulnerability influence grooming behaviour in humans? A comparative ethological perspective. Current Psychology, 29, 288-296.

Thornhill, R., Fincher, C. L. \& Aran, D. (2009). Parasites, democratization, and the liberalization of values across contemporary countries. Biological Reviews, 84, 113-131.

Thornhill, R., \& Gangestad, S. W. (1993). Human facial beauty: averageness, symmetry, and parasite resistance. Human Nature, 4, 237-269.

Thornhill, R., \& Gangestad, S. W. (2006). Facial sexual dimorphism, developmental stability, and susceptibility to disease in men and women. Evolution and Human Behavior, 27, 131-144.

Tomas, G., Merino, S., Moreno, J., \& Morales, J. (2007). Consequences of nest reuse for parasite burden and female health and condition in blue tits, Cyanistes caeruleus. Animal Behaviour, 73, 805-814.

Totaro, R. (2005). Suffering in paradise: The bubonic plague in English literature from More to Milton. 1st edition. Pittsburgh, Duquesne University Press, $251 \mathrm{pp}$.

Tybur, J. M., Lieberman, D. \& Griskevicius, V. (2009). Microbes, mating, and morality: Individual differences in three functional domains of disgust. Journal of Personality and Social Psychology, 97, 103-122.

Ungar, P. S., \& Teaford, M. F. (2002): Human diet: its origin and evolution (1 ${ }^{\text {st }}$ edition). Westport, CT: Bergin and Garvey.

Valencia-Mendoza, A., Bertozzi, S. M., Gutierrez, J. P., \& Itzler, R. (2008). Cost-effectiveness of introducing a rotavirus vaccine in developing countries: the case of Mexico. BMC Infectious Diseases, 8, 103.

Waller, B. M., Cray, J. J., Jr., \& Burrows, A.M. (2008). Selection for universal facial emotion. Emotion, 8, 435-439.

Walker, T. N., \& Hughes, W.O.H. (2009). Adaptive social immunity in leaf-cutting ants. Biology Letters, 5, 446-448.

Wedekind, C. (2002). Induced hatching to avoid infectious egg disease in whitefish. Current Biology, 12, 69-71.

Webster, J. P. (2007). The Effect of Toxoplasma gondii on animal behavior: Playing cat and mouse. Schizophrenia Bulletin, 33, 752-756.

Wheeler, P. E. (1984). The evolution of bipedality and loss of functional body hair in hominids. Journal of Human Evolution, 30, 357-366. 
Wilson-Rich, N., Spivak, M., \& Fefferman, N. H. (2009). Genetic, individual, and group facilitation of disease resistance in insect societies. Annual Review of Entomology, 54, 405-423.

Wolfe, N. D., Dunavan, C. P., \& Diamond, J. (2007). Origins of major human infectious diseases. Nature, 447, 279-283.

World Health Organization. 2010. World Health Statistics. Switzerland: WHO Press, 176 pp.

Wu, L. T. (1936). Chapter I: Historical aspects in Plague: A manual for medical and public health workers. Weishengshu, National Quarantine Service; Shanghai, pp. 1-55.

Yossa, N., Patel, J., Miller, P., \& Lo, Y. M. (2010). Antimicrobial activity of essential oils against Escherichia coli O157:H7 in organic soil. Food Control, 21, 1458-1465.

Zimmer, C. (2001). Parasite rex: Inside the bizarre world of nature's most dangerous creatures. 1st Touchstone edition. New York: Simon \& Schuster, 320 pp.

Advised by Julia Lakhvich, Belarusian State University, Republic of Belarus

Received: January 30, 2013

Accepted: March 14, 2013

Pavol Prokop PhD., Associate Professor, Department of Biology, Faculty of Education, Trnava University, Priemyselná 4, 91843 Trnava, Slovakia.

Department of Animal Ecology, Slovak Academy of Sciences, Dúbravská cesta 6, 84506 Bratislava, Slovakia.

E-mail: pavol.prokop@savba.sk

Website: http://www.zoo.sav.sk/prokop/

Peter Fedor PhD., Professor, Department of Ecosozology, Faculty of Natural Sciences, Comenius University, SK-84215 Slovakia.

E-mail: fedor@fns.uniba.sk

Website: http://www.fns.uniba.sk/index.php?id=3479 